\title{
An Early Educational Toy
}

\author{
By Mary Romano and Rebecca P. Butler
}

$\mathbf{T}$

his photograph is of a toy magic lantern. The magic lantern, or Lanterna Magica, first mentioned in the $1640 \mathrm{~s}$, is considered to be the earliest ancestor of the modern slide projector (Judson, 2009). Consisting of a source of light, a lantern slide and a projection lens, the magic lantern projected an enlarged image-painted on a glass plate or transparent paper-on a wall or screen. A variety of light sources were used to light the lantern, from simple candles to oil or gas lamps, and eventually electrified systems. As better light sources and inexpensive slides were developed, magic lantern usage thrived.

While entertainment was an important function of magic lanterns into the $20^{\text {th }}$ century, its greatest impact appeared in the world of education and the visual arts. In the $1880 \mathrm{~s}$, the popularity of the magic lantern spilled over into the world of children and play. Even though they presented fire hazards for unsupervised children, toy magic lanterns were manufactured in Europe and sold through mail order catalogs. Produced in different shapes and sizes, the magic lantern was considered an educational tool used in the instruction of physics, world geography, historic events, fairy tales, and moral stories.

The toy lantern's popularity waned in the 1920s, but professional projectors were used well into the 1940 s when the smaller, more com-

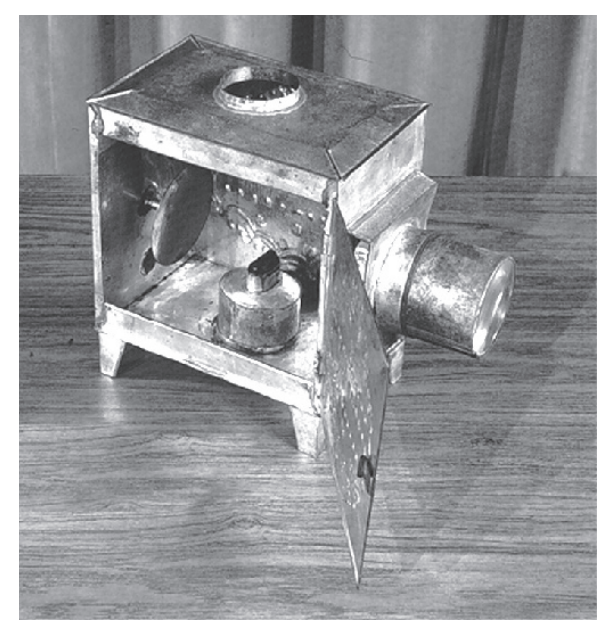

Lee and Lida Cochran AECT Archives Blackwell Museum of Education

Northern Illinois University, 1999

pact $35 \mathrm{~mm}$ slide format replaced them. Today, digital presentation tools allow users to visually entertain and inform quickly and easily, and flexible access and storage of digital images and light-weight portable LCD projectors have replaced the magic lanterns and their later counterparts.

\section{References}

Judson, J. (n.d.) The magic lantern. New England Antiques Journal Archives. Accessed April 15, 2009, from http://www.antiquesjournal.com/pages04/archives/magiclanterns.html

Lee and Lida Cochran AECT Archives. (1999). Toy Magic Lantern. DeKalb, IL: Blackwell Museum of Education, Northern Illinois University. Accessed April 15, 2009, from http://www.cedu.niu.edu/blackwell/multimedia/images/JPEGS/SLIDE044.JPG

\section{Idea Group REFERENCE}

The Premier Reference Source for Information Science and Technology Research

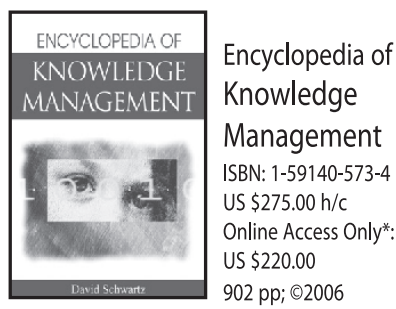

"It is a recommended reference work for all knowledge management (KM) libraries and any course dealing with $\mathrm{KM} . "$

- International Journal of Knowledge Management, Vol. 2(3)

Encyclopedia of

Distance

Learning

ISBN: 1-59140-555-6

US $\$ 995.00 \mathrm{~h} / \mathrm{c}$

Online Access Only*

US $\$ 796.00$

4-volume set

2,418 pp; $\odot 2005$

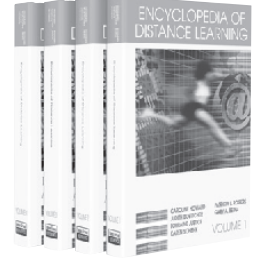

"This encyclopedia is an excellent reference tool for college, university, large public, or special libraries."

- CHOICE, October 2005

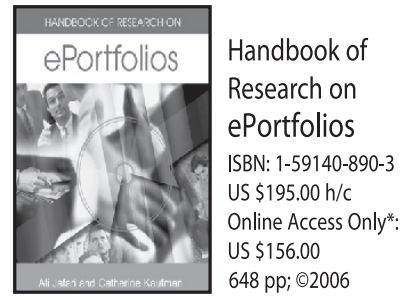

"This volume is accessible and likely to be a reference guide for years to come."

- Dr. Lev Gonick, Case Western Reserve University, USA

Free institution-wide online access with the purchase of a print copy!

*Online access is for libraries and is good for life of edition

Idea Group Reference 701 E. Chocolate Ave., Suite 200 Hershey PA 17033, USA 1-866-342-6657 (toll free) cust@idea-group.com

www.idea-group-ref.com 